\title{
COMPARISON OF EARNINGS MANAGEMENT IN EACH NON-FINANCIAL SECTOR OF BUMN LISTED ON THE IDX
}

\author{
Shintya Fransiska \\ Universitas Ciputra Surabaya
}

\begin{abstract}
This research was conducted to determine whether there are differences in each non-financial sector of BUMN listed on the IDX in carrying out earnings management practices. The research sample includes a saturated sampling method. The research sample consisted of 19 companies were divided into 8 sectors. The amount of data used is 225 data from 2006-2019. Earnings management will be measured using discretionary accruals with a Modified Jones model. The hypothesis was tested using the Kruskal Wallis test and followed by the Dunn test. The results show that there are differences in the level of earnings management in each nonfinancial sector of BUMN listed on the IDX. The difference is due to the higher level of earnings management carried out by the construction sector compare to the other sectors. Furthermore, the metal sector has the lowest average level of earnings management practices.
\end{abstract}

Keywords: earnings management, accrual, and BUMN

\section{INTRODUCTION}

Earnings management is an intervention activity in financial reporting to achieve certain goals in obtaining profits (Schipper, 1989). Therefore, company is encouraged to carry out earnings management practices to attract investors. However, investors are opposing the earnings management practices as the practices can lead to information asymmetry (Manggau, 2016). According to a study by Lesmana \& Sukartha (2017), earnings management can affect the quality of financial statements report and earnings management has a positive effect on firm value. With the increase of company value, it encourages investors

\footnotetext{
"Corresponding Author.

e-mail: shintyafransiska624@gmail.com
} 
to invest in the company. Therefore, the company managers seek to increase firm value to carry out earnings management practice.

With the existence of earnings management comparisons, each company can find out the high and low earnings management practices that are carried out. Earning management that is too high will make the public doubt the financial statements that was made and question the accounting standards used by the company. According to Subadriyah et al. (2020), although earnings management is carried out without violating the accounting standards, earnings management is an act of corruption because it is motivated by the interests of certain parties and is carried out on purpose. Therefore, a high earnings management can damage the economic order and cause the public to question the responsible business life. Profit management that is too high can also encourage someone to commit economic crimes, for example the Enron case.

This research is using BUMN (Badan Usaha Milik Negara or state-owned enterprises) because BUMN has an important role in Indonesia's economy (Undang-Undang BUMN Pasal 2 No. 19 tahun 2003). Their role is to be the manager of state-owned natural resources, a source of state income in addition to taxes, and provides employment for the community. Since 2019, several BUMN shares have catch public attention as soon as the BUMN shares are being sold. In addition, BUMN received attention from various problems that occurred (Kevin, 2019). For example, problems related to financial reports in several BUMN companies, including PT Garuda Indonesia, PLN, and Pertamina.

Some of the problems that occur in BUMN are due to BUMN poor performance, and it has impacted on their shares (Kevin, 2019). Therefore, several BUMN companies are indicated to carry out earnings management practice in their financial reports by increasing profit to attract more investors and increase the company value (Sandi, 2020). In addition, the agency theory also encourages BUMN to carry out earnings management practice. This is supported by previous research conducted by Yimenu \& Surur (2019) which found that agency theory proxies and signalling theory proxies have a positive and significant relationship with earnings management.

The performance of BUMN is also becoming a concern for the government because BUMN often report low profits or losses. Thus, BUMN is encouraged to provide good financial information and one of the ways is to carry out 
earnings management practice. According to this issue, Salim \& Djuminah (2018) examined that a high earnings management will have an impact on the economic health of BUMN. This is because high earnings management only benefits short-term, not long-term sustainability, while BUMN is holds an important role for economic sustainability in Indonesia.

Watts \& Zimmerman (1986), Scott (1997), and Scott (2000) stated that there are several motivations for managers to carry out earnings management practice. First, the high compensation of bonus plan that the manager strives to get. By showing good performance, it encourages the managers to carry out earnings management if the resulting performance decreases. This supports the results of a research by Ulupui et al. (2019) showing that BUMN managers are encouraged to carry out earnings management practice to get higher compensation. Second, a long-term debt contract, where the manager will carry out earnings management practice if the company approaches a debt covenant violation. Therefore, managers are carrying out earnings management practice by choosing an accounting method that can move future earnings to the current period. This supports the results of a study by Pernamasari (2018), which stated the cost of debt affects BUMN earnings management, so that BUMN carries out earnings management to improve the company's reputation.

Third, political motivation where large companies with high profits have the tendency to carry out negative earnings management practice to reduce their visibility. This is because the company is motivated to get assistance from the government, such as subsidies. Fourth, taxation motivation where a company is encouraged to report low profits if the generated profits is too high. The company is motivated to minimize the taxes that must be paid. Thus, a company that has high profits are more likely to do earnings management.

Fifth, the replacement of the Chief Executive Officer (CEO). The CEO whose term of service will end is encouraged to get bonuses by showing good performance. Therefore, CEO who have poor performance are encouraged to carry out earnings management practice. This is supported by one of Sadia \& Sukartha's (2014) research, where it stated that the CEO of BUMN who will be replaced is motivated to carry out earnings management practice. Sixth, an initial public offering, in which companies that are wishing to conduct an initial public offering is encouraged to carry out earnings management practice. This is 
because the company wants to provide good financial information. Good financial information provides a positive signal for investors to invest. This theory supports the research results by Prayogo \& Gunawan (2018), which found that BUMN who wants to go public is carrying out earnings management two years before the IPO (Initial Public Offering) because BUMN wants to provide positive financial information to attract investors.

There are several business strategies to perform earnings management. Earnings management strategies is divided into two, which are artificial earnings management and transactional earnings management (Stolowy \& Breton, 2004). Artificial management is when a company is taking advantage of flexible accounting principles and violations. According to Beneish (1997) and Dechow et al. (1995), the flexibilities includes: (a) There is an account receivable expense due to the estimated allowance for accounts receivable; (b) There is an inventories expense due to the estimated allowance for inventories; (c) There is a depreciation expense due to the estimated life of the asset or the depreciation rate (Neil et al., 1995) and (Michelson et al., 1995); (d) There is an amortization expense for deferred costs as a result of the estimated useful lives of deferred costs (Beneish, 1997) and (Moses, 1987). From these descriptions, a company has the freedom to estimate its expenses. This is different with violations on accounting principles. Forms of violations of accounting principles includes errors in calculating cost of goods sold, reporting negative goodwill, and misleading report of losses on lost inventories.

Transactional earnings management is a practice that involves external parties to create transactions or operations, thus impacted to the company profits. For example, acquisition transactions, divestment transactions, and transactions with parties that have a special relationship with the company. These strategies include: (a) Loss on foreign exchange due to purchasing imports in foreign currency (Brayshawand \& Eldin, 1989); (b) Acquisition of another profitable company or divestment of a loss-making subsidiary (Beneish M. D., 1999); (c) The recording of revenue and fictitious cost of goods sold in the recognition of commission income as sales intermediary; (d) Misrepresentation of the transactions reporting between companies or between parties in a relationship. 
According to Scott (2003), there are several patterns that managers often do in earnings management, which are:

a. Taking a bath

Managers will write off assets so that future profits can increase. This is because managers are required by the company to report high profits. Accordingly, costs in the future periods are recognized for the current period, which causes future profits to increase.

b. Income Minimization

Company that has a high profitability will be motivated to carry out earnings management practice by reducing profits through the elimination of intangible assets, advertising costs, research or development costs, and accounting results for exploration costs. The company's goal to carry out earnings management practice is due to tax and political motivation.

c. Income Maximization

Managers who are motivated by the bonus plan will be encouraged to carry out earnings management practice by increasing the company's profits. This is done by managers if the company's performance decreases, as well as when the company is close to violating debt covenants.

d. Income Smoothing

The company will perform income smoothing to report positive financial information. This is encouraged so that the company provides positive signals for investors.

Financial reports that are prepared using the accrual accounting system provide opportunities for managers to carry out earnings management practice (Dahlan, 2009). Christiani \& Nugrahanti (2014) explain that there are two concepts of accrual models, which are discretionary accruals and non-discretionary accruals. Discretionary accruals are a component of accruals that can be arranged and engineered in accordance with the manager policies. For example, a manager can manage expenses and income in the following ways: (a) There are account receivables that are uncollectible at the end of the financial year. So, the manager has determined the charges based on the consideration of charging in the next period or in the current period; (b) Managers can control depreciation and amortization costs by estimating the economic life of the assets owned by the 
company; (c) The manager controls the cost of claiming on guarantee to get high profit for the current year by recognizing the cost of claiming on guarantee for the following period.

Furthermore, non-discretionary accruals are a component of accruals that cannot be regulated or engineered in accordance with the manager policies. Nondiscretionary accruals component is a fixed component used by all companies. For example, the depreciation and inventory methods used by the company must be in accordance with the methods recognized in the accounting principles. Therefore, the company cannot change the non-discretionary accruals component to increase their profit.

There are several research that has examined earnings management, including:

1. Mostafa (2017) examined the relationship between earnings management and the value relevance of earnings. The results show that a company with low operating performance must carry out earnings management, resulting in low earnings value relevance.

2. Pattanayak (2017) examined the comparison of earnings management in the public and private commercial banking industry in India. The results of this study indicate an increase in earnings management practices in both private sector bank and public sector commercial banks.

3. Santoso (2018) examined the comparison of earnings management in Islamic banking and conventional banking in Indonesia. The results show that Islamic banks has a lower level of earnings management compare to conventional banks.

4. Asni \& Mayasari (2018) examined the comparisons before and after IFRS adoption on accrual earnings management and real earnings management. The results show that there is no difference in accrual earnings management before and after IFRS adoption, while real earnings management shows differences.

5. Prabowo (2019) examined the effect of company loss performance on earnings management. The results show that company that has a loss of performance will encourage the managers to carry out earnings management practice because the managers try to maintain their position. 
6. Said (2019) examined the impact of IFRS implementation on earnings management practices in Canadian companies. The results show that the application of IFRS has no effect on earnings management practices.

7. Ulupui et al. (2019) examined the effect of discretionary accruals on board compensation. The results show that discretionary accruals influence executive compensation in BUMN.

8. Okofo et al. (2020) examined the effect of the global financial crisis on the relationship between CEO compensation and earnings management. The results show that CEO compensation and earnings management increased during the financial crisis period.

9. Priscilla \& Siregar (2020) examined the effect of management expertise (TMT) on real earnings management activities and accrual earnings management. The results showed that the expertise of TMT members had no effect on accrual earnings management but influenced real earnings management through cash flow and discretionary costs.

With the understanding from past studies mentioned above, this research aims to determine whether each non-financial sector of BUMN carry out earnings management practice and whether there are differences in the level of earnings management in each sector. The results of this research are expected to provide information to the government, to better supervise and evaluate the performance of BUMN companies that carry out the highest earnings management practices. Furthermore, this research can provide information to investors by considering the aspects of earnings management in investing. The hypothesis in this research is formulated as follow:

H1: There are differences in earnings management on BUMN financial reports in each non-financial sector.

\section{METHOD}

\section{Population and Sample}

The population group of this research includes the non-financial sector of BUMN companies listed on the Indonesia Stock Exchange consisting of 19 companies from 8 sectors. The sample of this research is obtained via a saturated sampling 
technique; thus, that the entire population was used in the sample group. The amount of data used is 225 data obtained from 2006-2019. This research uses secondary data resources taken from the financial statements of BUMN companies in the non-financial sectors. Measurement scale is based on ratio.

\section{Operational Definition and Variable Measurement}

Earnings management in this research is measured using the Jones Modified model. The level of earnings management is measured by the amount of total discretionary accruals (DA). The formula is formulated as follow (Dechow et al., 1995):

1. Calculating the total accruals (TAC), that is the net income in year $t$ minus the operating cash flow in year $t$ with the following formula:

TAC $=$ Nlit - CFOit

Furthermore, total accrual (TA) is estimated using ordinary least square as follow:

$$
\frac{T A_{i t}}{A_{i t-1}}=\beta_{1}\left(\frac{1}{A_{i t-1}}\right)+\beta_{2}\left(\frac{\Delta R e v_{i t}}{A_{i t-1}}\right)+\beta 3\left(\frac{P P E_{i t}}{A_{i t-1}}\right)
$$

2. With the regression coefficient calculated with the formula above, the nondiscretionary accrual (NDA) is determined by the following formula:

$$
N D A_{i t}=\beta_{1}\left(\frac{1}{A_{i t-1}}\right)+\beta_{2}\left(\frac{\Delta \operatorname{Rev}_{i t}}{A_{i t-1}}-\frac{\Delta \operatorname{Rec}_{i t}}{A_{i t-1}}\right)+\beta 3\left(\frac{P P E_{i t}}{A_{i t-1}}\right)
$$

3. Finally, discretionary accruals (DA) as a measure of earning management is determined by the following formula:

$$
D A_{i t}=\frac{T A_{i t}}{A_{i t-1}}-N D A_{i t}
$$

Information:

DAit $=$ Discretionary accruals of company $\mathrm{i}$ in year period $\mathrm{t}$

NDAit $=$ Nondiscretionary accruals of company $\mathrm{i}$ in year period $\mathrm{t}$

TAit $=$ Total accrual of company $\mathrm{i}$ in year period $\mathrm{t}$

NIit $=$ Net profit of company I in year period $t$

CFOit $=$ Cash flow from operating activities of company $\mathrm{i}$ in year period $\mathrm{t}$ Ait-1 = total assets of company $\mathrm{i}$ in year period $\mathrm{t}-1$ 
$\Delta$ Revit $=$ Company income $\mathrm{i}$ in year $\mathrm{t}$ less company income $\mathrm{i}$ in year $\mathrm{t}-1$

PPEit = Property, factory, and equipment company $\mathrm{i}$ in year period $\mathrm{t}$

$\Delta$ Rec_it $_{-}=$Accounts Receivable of company $\mathrm{i}$ in year $\mathrm{t}$ less company income

\section{Data Analysis Method}

This research uses comparative quantitative research method. Thus, this research compares the amount of earnings management in BUMN companies from the non-financial sectors using company financial statement data taken from 2006-2019.

\section{RESULTS}

\section{Descriptive Statistic}

Table 1 Descriptive Statistic

\begin{tabular}{lcccccc}
\hline \multicolumn{1}{c}{ Sector } & N & Range & Minimum & Maximum & Mean & Std. Deviation \\
\hline Pharmaceutical & 26 & 0.01456 & -0.00453 & 0.01003 & 0.00145 & 0.00068 \\
Energy & 14 & 0.00405 & -0.00110 & 0.00294 & 0.00091 & 0.00030 \\
Metal & 12 & 0.00761 & -0.00232 & 0.00529 & 0.00012 & 0.00071 \\
Construction & 57 & 0.02781 & -0.00691 & 0.02089 & 0.00482 & 0.00071 \\
Mining & 42 & 0.02231 & -0.00804 & 0.01427 & 0.00129 & 0.00069 \\
Cement & 35 & 0.05126 & -0.01089 & 0.04037 & 0.00225 & 0.00133 \\
Transportation & 27 & 0.02186 & -0.00661 & 0.01524 & 0.00067 & 0.00078 \\
Telecommunications & 12 & 0.00091 & -0.00002 & 0.00090 & 0.00035 & 0.00008 \\
\hline
\end{tabular}

The calculation of earnings management in this research is measured by the level of discretionary accruals carried out by the company. From the results of the descriptive statistics (Table 1), it is evident that all BUMN sectors are carrying out accrual earnings management. The minimum value for discretionary accrual amounting 0.00002 lies in the telecommunications sector and the maximum value for discretionary accruals amounting 0.04037 lies in the cement sector. Therefore, the telecommunications sector has the lowest discretionary accrual rate compared to other sectors; even if the maximum value of discretionary accrual made by the telecommunications sector is only 0.00090 .

Based on Table 1, the highest average value for discretionary accruals was carried out by the construction sector at 0.00482 . It may indicate that the construction sector always carries out earnings management. The construction 
sector is also recorded as the second highest in the maximum value of discretionary accrual. Therefore, the construction sector often uses the accrual method in reporting its income.

Based on Table 1, the lowest average value for discretionary accruals is carried out by the metal sector at 0.00012 . It can be said that the metal sector uses less earnings management in reporting its financial statements. In addition, the level of earning management is low because the sector only consists of one company, which is PT Krakatau Steel.

\section{Normality Test and Homogeneity Test}

Based on the results of the normality test shown in Table 2, some data are found as not normally distributed because the value is $<0.05$. Furthermore, based on the results of the homogeneity test shown in Table 3 , the data is not homogeneous because the value is $<0.05$. This means that the earnings management in each sector is far from vulnerable. Thus, the test is required to be delivered through the Kruskal Wallis Test method.

Table 2 Normality Test

\begin{tabular}{llccc}
\hline \multicolumn{4}{c}{ Tests of Normality } \\
\cline { 3 - 5 } & \multirow{2}{*}{ Sector } & \multicolumn{3}{c}{ Shapiro-Wilk } \\
\cline { 3 - 5 } Earnings & Sharmaceutical & 0,946 & df & Sig. \\
Management & Energy & 0,967 & 14 & 0,183 \\
& Metal & 0,859 & 12 & 0,829 \\
& Construction & 0,931 & 57 & 0,047 \\
& Mining & 0,973 & 42 & 0,401 \\
& Cement & 0,550 & 35 & 0,000 \\
& Transportation & 0,799 & 27 & 0,000 \\
& Telecommunications & 0,940 & 12 & 0,503 \\
\hline
\end{tabular}

Table 3 Homogeneity Test

\begin{tabular}{cccc}
\hline \multicolumn{4}{c}{ Test of Homogeneity of Variances } \\
\hline \multicolumn{4}{c}{ Earnings Management } \\
\hline $\begin{array}{c}\text { Levene } \\
\text { Statistic }\end{array}$ & df1 & df2 & Sig. \\
\hline 2.395 & 7 & 217 & .022 \\
\hline
\end{tabular}


Table 4 Kruskal Wallis Test

\begin{tabular}{lr}
\hline \multicolumn{2}{c}{ Test Statistics ${ }^{\mathbf{a}, \mathbf{b}}$} \\
\hline & \multicolumn{2}{c}{ Manajemen_Laba } \\
\cline { 2 - 2 } Chi-Square & 38.131 \\
df & 7 \\
Asymp. Sig. & .000 \\
a. Kruskal Wallis Test & \\
b. Grouping Variable: Sektor & \\
\hline
\end{tabular}

The Kruskal Wallis test results is shown in Table 4 and it indicates a value of $<0.05$, thus $\mathrm{H} 1$ is accepted. This means that there are differences in the level of earnings management within the non-financial sector of BUMN.

\section{Dunn's Test}

Table 5 Dunn's Test

\begin{tabular}{lrrrrr}
\hline \multicolumn{1}{c}{ Sample 1-Sample 2 } & Test Statistic & Std. Error & $\begin{array}{c}\text { Std. Test } \\
\text { Statistic }\end{array}$ & Sig. & Adj.Sig. \\
\hline Metal- Telecommunications & $-5,833$ & 26,575 & $-0,220$ & 0,826 & 1,000 \\
Metal- Transportation & $-13,352$ & 22,585 & $-0,591$ & 0,554 & 1,000 \\
Metal -Energy & 27,976 & 25,609 & 1,092 & 0,275 & 1,000 \\
Metal - Mining & $-34,333$ & 21,308 & $-1,611$ & 0,107 & 1,000 \\
Metal - Cement & $-35,748$ & 21,776 & $-1,642$ & 0,101 & 1,000 \\
Metal - Pharmaceutical & 36,372 & 22,718 & 1,601 & 0,109 & 1,000 \\
Metal - Construction & $-82,921$ & 20,675 & $-4,011$ & 0,000 & 0,002 \\
Telecommunications-Transportation & 7,519 & 22,585 & 0,333 & 0,739 & 1,000 \\
Telecommunications -Energy & 22,143 & 25,609 & 0,865 & 0,387 & 1,000 \\
Telecommunications- Mining & 28,500 & 21,308 & 1,338 & 0,181 & 1,000 \\
Telecommunications - Cement & 29,914 & 21,776 & 1,374 & 0,170 & 1,000 \\
Telecommunications - Pharmaceutical & 30,538 & 22,718 & 1,344 & 0,179 & 1,000 \\
Telecommunications - Construction & 77,088 & 20,675 & 3,728 & 0,000 & 0,005 \\
Transportation -Energy & 14,624 & 21,439 & 0,682 & 0,495 & 1,000 \\
Transportation - Mining & 20,981 & 16,057 & 1,307 & 0,191 & 1,000 \\
Transportation - Cement & 22,396 & 16,674 & 1,343 & 0,179 & 1,000 \\
Transportation - Pharmaceutical & 23,020 & 17,886 & 1,287 & 0,198 & 1,000 \\
Transportation - Construction & 69,569 & 15,208 & 4,574 & 0,000 & 0,000 \\
Energy- Mining & $-6,357$ & 20,089 & $-0,316$ & 0,752 & 1,000 \\
Energy- Cement & $-7,771$ & 20,585 & $-0,378$ & 0,706 & 1,000 \\
Energy- Pharmaceutical & 8,396 & 21,579 & 0,389 & 0,697 & 1,000 \\
Energy- Construction & $-54,945$ & 19,417 & $-2,830$ & 0,005 & 0,130 \\
Mining - Cement & $-1,414$ & 14,898 & $-0,095$ & 0,924 & 1,000 \\
Mining - Pharmaceutical & 2,038 & 16,244 & 0,125 & 0,900 & 1,000 \\
Mining - Construction & 48,588 & 13,238 & 3,670 & 0,000 & 0,007 \\
Cement - Pharmaceutical & 0,624 & 16,854 & 0,037 & 0,970 & 1,000 \\
Cement - Construction & 47,173 & 13,979 & 3,375 & 0,001 & 0,021 \\
Pharmaceutical - Construction & $-46,549$ & 15,405 & $-3,022$ & 0,003 & 0,070 \\
\hline & & & & &
\end{tabular}


Dunn's test decision making is based on a significance level of $<0.05$ where it means that there are differences in the level of earnings management carried out for each of these sectors. Conversely, sectors with a significance level of $>0.05$ means that there is no difference in the level of earnings management.

Based on Table 5, there are differences in the level of earnings management for several sectors, which are metal-construction, telecommunications-construction, transportation-construction, mining-construction, and cement-construction sectors. On the other hand, the other sectors, which are metal-telecommunications, metal-transportation, metal-energy, metal-mining, metal-cement, metalpharmaceutical, telecommunications-transport, telecommunications-energy, telecommunications-mining, telecommunications-cement, telecommunications- pharmaceutical, energy-transport, mining-transport, cement-transport, pharmaceutical-transport, energy-mining, energy-cement, energy-pharmaceuticals, miningcement, mining-pharmaceuticals, cement-pharmaceuticals, energy-construction, and pharmaceutical-construction have no difference in the level of earnings management.

\section{DISCUSSION}

Based on the calculation of earnings management (Table 1), the cement sector is carrying out earnings management practice with the highest value of 0.04037. The earnings management was carried out in 2016 by PT Waskita Beton Precast because the company conducted an initial public offering. Thus, PT Waskita Beton Precast carried out earnings management before conducting an initial public offering to provide good financial information. This supports a research by Prayogo \& Gunawan (2018) stating that when a company is going to go public, they are encouraged to carry out earnings management practice by increasing its profits to attract investors.

Based on the calculation of earnings management (Table 1), the construction sector is in the second highest score to carry out earnings management practice at 0.02089 . This number was carried out by the PT PP Properti in 2016. In 2015, PT PP Properti made an initial public offering. Therefore, from 2014 (before the IPO) to 2016 (after the IPO), PT PP Properti was carried out earnings management practice which increased every year. This is evidenced by the increase in the 
price of shares owned by PT PP Properti from 2015-2016. By carry out earnings management, PT PP Properti can attract investors to invest (Yimenu \& Surur, 2019). These results support a research of Prayogo \& Gunawan (2018), which states that company that will go public is encouraged to carry out earnings management practice.

Based on the calculation of earnings management (Table 1), transportation sector is in the third highest position to carry out earnings management practice at 0.01524 . This number was carried out by the PT Jasa Marga in 2016. This is because account receivables in 2016 increased by 50 times from 2015. A too high level of account receivables can impact on default or turnover of account receivables that is too long (Sangka, Elim, \& Walandouw, 2018). Thus, the company is carrying out earnings management practice because it has abnormal account receivables (Stubben, 2010) and the company wants to provide a good financial information to the investors. The accrual method also provides an opportunity for managers to recognize income earlier.

Based on the calculation of earnings management (Table 1), the mining sector is in the fourth highest value to carry out earnings management practice at 0.01427 . This number was made by the PT Bukit Asam company in 2008 . This is because in 2018, account receivables and the company's net profit have increased. It can be assumed that the increase in profit is due to the sale of recognized account receivables (Stubben, 2010). This result is driven by the accrual accounting method which provides opportunities for managers to recognize earnings earlier.

Based on the calculation of earnings management (Table 1), the pharmaceutical sector is in the fifth place to carry out earnings management practice at 0.01003. This number was carried out by the PT Kimia Farma in 2019. The company has a decrease in net income, thus encouraging the company to carry out earnings management practice so that net income does not show a minus (loss) value. This result supports Mostafa's (2017) research indicating that a decline of company performance will motivate the company to carry out earnings management practices. In addition, managers deliberately carry out earnings management practice to avoid disciplinary mechanisms because the company's poor performance will have an impact on the manager's career (Prabowo, 2019). Another driving factor is bonus compensation (Ulupui et al., 
2019). Managers are entitled to receive high bonuses when they show a good performance against the company.

Based on the calculation of earnings management (Table 1), the metal sector is in the sixth place to carry out earnings management practice at 0.00529 . This number was carried out by the PT Krakatau Steel company in 2012. This is because the company's income in 2012 suffered a loss. Thus, the company will be encouraged to carry out high earnings management practice (Prabowo, 2019) to provide positive indicators to the investors (Yimenu \& Surur, 2019) and to give a chance for the managers to get bonus compensation (Ulupui et al., 2019).

Based on the calculation of earnings management (Table 1), the energy sector is in the seventh place to carry out earnings management practice at 0.00294. This number was carried out by PT Perusahaan Gas Negara in 2018 . The company's account receivables held in 2018 was higher than other years. Therefore, accounts receivable that is too high or too low is indicated to have a management in revenue (Stubben, 2010). This result is supported by the accrual method which provides opportunities for managers to carry out earnings management practice and allow the company to provide a positive financial information so that they look good to the investors.

Based on the calculation of earnings management (Table 1), the telecommunications sector is the last to carry out earnings management practice with the highest score at 0.000895801 . This number was carried out by the PT Telekomunikasi Indonesia in 2018. This number is due to the decline in net income in 2018, even when the account receivables owned by the company increased. Therefore, the company has experienced a decline in its performance, so that the company is encouraged to carry out earnings management practice (Mostafa, 2017). The fact that telecommunications sector is in the lowest position in conducting earnings management means that the telecommunications sector shows a good performance. This can be seen from the value of the net profit that is owned and the company's tendency to always show profits from the initial IPO until 2019. Thus, the telecommunications sector does not want to carry out earnings management practice because high earnings management can reduce earnings quality (Asni \& Mayasari, 2018).

The Kruskal Wallis test results (Table 4) show that the significance level is $<0.05$, which is equal to 0.000 . This means that there are differences in the level 
of earnings management carried out in each non-financial BUMN sector. Based on the results of the Dunn test (Table 5), it shows that the construction sector has different levels of earnings management compared to other sectors. This difference may be explained by the finding where the construction sector's average value shows the highest value in earnings management, which is 0.00482 .

The construction sector is a priority because the government focuses on infrastructure to build economic growth in Indonesia. In addition, the government has increased the budget for infrastructure every year (kemenkeu, 2020). With the increase in the infrastructure budget, it impacted on the income earned by the construction sector. This is supported by their financial statements showing that each year the company has increased in sales. However, they also show an increase in earnings management.

The construction sector has the highest average score in carrying out earnings management practices, so it can be interpreted that the construction sector often uses earnings management in its financial reporting. The incentive to do earnings management can be due to account receivables. Each year, the sales of account receivables owned by the construction sector for has increased as the government does not directly pay the final work. Thus, the construction sector can perform earnings management using the accrual method. For example, recognizing revenue from sales of account receivables even when the payment has not been received (Christiani \& Nugrahanti, 2014). Another supporting factor is to attract investors. With earnings management, the company can provide financial information that looks promising. Financial report is an important information for investors to make investment decisions (Prayogo \& Gunawan, 2018).

The average result of earnings management carried out by the construction sector can affect the quality of the reported earnings. Therefore, it can be assumed that the increase in income owned by the construction sector does not come entirely from a good company performance. These results are supported by previous research showing that earnings management has an impact on financial statement information because it does not reflect the real conditions (Riswandi $\&$ Yuniarti, 2020). This rises information asymmetry between the investors and the company (Manggau, 2016). 
The metal sector has the lowest average score to carry out earnings management practice. The metal sector only consists of one company, which is PT Krakatau Steel. The low level of earnings management is evidenced by the results of the net income reported by the company from 2012-2019 showing that the company was suffering a loss. Annually, the losses is increasing, but the company still reports honestly. Therefore, it can be said that PT Krakatau Steel does not has much change its financial reports via earnings management practices. Thus, the financial statements will show a better quality compare to the other sectors (Asni \& Mayasari, 2018).

The factor that can encourage the metal sector to show the lowest average earnings management is the quality of its financial reports because earnings management can mislead the reported information. Therefore, earnings management causes information asymmetry, thus mislead the investors who want to know the real company's performance (Asni \& Mayasari, 2018). Another driving factor is to gain investor confidence. Earnings management that is too high will reduce investor confidence in the reported financial reports (Yimenu \& Surur, 2019) and the relevance of low earnings values (Mostafa, 2017).

\section{Conclusions and Implications}

This research concludes that every non-financial BUMN sector carries out earnings management practice. The level of earnings management that each sector has is different because each sector has a different incentive. This impulse is due to certain interests in the company, which is in line with agency theory.

The results of this research indicate that the construction sector has the most significant level of difference compared to other sectors. This is because the construction sector has the highest average in earnings management practice. The factor that can encourage the construction sector to have the highest average is account receivables because the account receivables owned by the construction sector has increased every year. Thus, account receivables that is too high encourages the company to recognize their income quicker.

This research shows that the metal sector has the lowest average in earnings management practice. This may happened because a high earnings management may resulted in lower investor's confidence. Earnings management also results in 
information asymmetry. Thus, the metal sector does not carry out excessively high earnings management, so the profit reported by the metal sector has a better quality than the other sectors.

The implication of this research can provide information to investors to consider the level of earnings management in investing in non-financial companies of BUMN. The government can also find out which sectors has the highest level of earnings management. This makes it easier for the government to monitor the performance and financial information reported.

\section{Limitations and Suggestions}

This research has several limitations. First, the data owned is not normally distributed. Second, the data used for this study obtained from 2006-2019 is not entirely owned by the companies because some companies did not conducted IPO in 2006. Future research is suggested to include factors that influence earnings management practices, for example, CEO compensation, ownership structure, corporate governance, and audit quality.

\section{REFERENCES}

Asni, F. \& Mayasari, M. (2018). Perbedaan Sebelum dan Sesudah Adopsi terhadap Manajemen Laba Akrual dan Manajemen Laba Riil pada Perusahaan Manufaktur yang Terdaftar di BEI. Journal of Applied Managerial Accounting, 2(1), 82-87.

Beneish, M. (1997). Detecting GAAP Violation: Implications for Assessing Earnings Management among Firms with Extreme Financial Performance. Journal of Accounting and Public Policy, 16, 271-309.

Beneish, M. D. (1999). Incentives and Penalties Related to Earnings Overstatements that Violate GAAP. The Accounting Review, 74(4), 425-458.

Brayshawand, R. E. \& Eldin, A. E. (1989). The Smoothing Hypothesis and the Role of Exchange Differences. Journal of Business Finance and Accounting, 16(5), 621-633.

Christiani, I. \& Nugrahanti, Y. W. (2014). Pengaruh Kualitas Audit terhadap Manajemen Laba. Jurnal Akuntansi dan Keuangan, 16(1), 52-62. 
Dahlan, M. 2009. Analisis Hubungan antara Kualitas Audit dengan Diskresioner Akrual dan Kebebasan Auditor. Working paper. Universitas Padjajaran.

Dechow, P., Sloan, R. G., \& Sweeny, A. P. (1995). Detecting Earnings Management. The Accounting Review, 70(2), 193-225.

Indonesia. Kementerian Keuangan. https://www.kemenkeu.go.id/apbn2020.

Indonesia. Undang-Undang Badan Usaha Milik Negara, Pasal 2 UU No. 19 Tahun 2003.

Kevin, A. (2019). 3 'Borok' BUMN: Rugi, Poles Laporan Keuangan, Korupsi Retrieved from cnbcindonesia: https://www.cnbcindonesia.com/news/ 20190802155045-4-89438/3-borok-bumn-rugi-poles-laporan-keuangankorupsi

Lesmana, I. S. \& Sukartha, I. M. (2017). Pengaruh Manajemen Laba pada Nilai Perusahaan Manufaktur yang Terdaftar di Bursa Efek Indonesia Tahun 2012-2015. E-Jurnal Akuntansi Universitas Udayana, 19(2), 1060-1087.

Manggau, A. W. (2016). Pengaruh Asimetri Informasi dan Ukuran Perusahaan terhadap Manajemen Laba pada Perusahaan Pertambangan yang Terdapat di Bursa Efek Indonesia. Jurnal Ekonomi dan Keuangan, 13(2), 103-114. doi: http://dx.doi.org/10.29264/jakt.v13i2.1177.

Michelson, S. E., Wagner, J. J., \& Wooton, C. W. (1995). A Market based Analysis of Income Smoothing. Journal of Business Finance \& Accounting, 22(8), 1179-1193.

Moses, O. D. (1987). Income Smoothing and Incentive: Empirical Tests using Accounting Changes. The Accounting Review, 62(2), 358-377.

Mostafa, W. (2017). The impact of earnings management on the value relevance of earnings Empirical evidence from Egypt. Managerial Auditing Journal, 32(1), 50-74.

Neill, J. D., Pourciau, S. G., \& Schaefer, T. F. (1995). Accounting Method Choice and IPO Valuation. American Accounting Association, 9(3), 68-80.

Okofo, O. A., Ali, M. J., \& Ahmed, K. (2020). The effects of global financial crisis on the relationship between CEO compensation and earnings management. 28(2), 389-408. doi:10.1108/IJAIM-08-2019-0101.

Pattanayak, P. K. (2017). Linking earnings management practices and corporate governance system with the firms' financial performance: a study of Indian commercial banks. Journal of Financial Crime, 24(2), 223-241. 
Pernamasari, R. (2018). Penerapan Good Corporate Governance dan Earning Management terhadap Biaya Utang pada Perusahaan BUMN Listing CGPI 2010-2012. Profita, 11(1), 67-80.

Prabowo, M. A. (2019). Kinerja Rugi dan Manajemen Laba di Indonesia: Perspektif Governance. Jurnal Akuntansi dan Bisnis, 19(2), 134-146.

Prayogo, B. \& Gunawan, I. (2018). Evaluasi Perataan Laba pada Kinerja Badan Usaha Milik Negara Sebelum dan Setelah Menjadi Perusahaan Terbuka di Indonesia. Indonesian Journal of Accounting and Governance (IJAG), 2(1), $65-95$.

Priscilla, M. \& Siregar, S. V. (2020). The Effect of Top Management Team Expertise on Corporate's Accrual and Real Earnings Management. International Symposia in Economic Theory and Econometrics, 27(79-101). doi:10.1108/S1571-038620200000027007.

Riswandi, P. \& Yuniarti, R. (2020). Pengaruh Manajemen Laba Terhadap Nilai Perusahaan. Pamator, 13(1), 134-138.

Sadia, N. \& Sukartha, I. (2014). Pengaruh Pergantian CEO pada Praktik Manajemen Laba Perusahaan Publik yang Terdaftar di Bursa Efek Indonesia. E-Jurnal Akuntansi Universitas Udayana, 8(1), 200-210.

Said, K. (2019). The Impact of IFRS Adoption on Earnings Management Results from Canada. Journal of Economics and Business, 2(3), 540-554.

Salim, M. \& Djuminah. (2018). Pengaruh Manajemen Laba Terhadap Tingkat Kesehatan Bumn di Indonesia. Seminar Nasional Tahun 2018 (pp. 368377). Hasil Penelitian dan Pengabdian kepada Masyarakat.

Sandi, F. (2020). Erick Thohir Akhirnya Ungkap Modus BUMN Vermak Lapkeu, Dub! Retrieved from cnbcindonesia: https://www.cnbcindonesia.com/market/20200111122513-17-129350/erick-thohir-akhirnya-ungkap-modusbumn-vermak-lapkeu-duh

Sangka, S., Elim, I., \& Walandouw, S. (2018). Analisis Tingkat Perputaran Piutang Usaha Terhadap Laporan Arus Kas Operasi pada Manado Quality Hotel. Jurnal Riset Akuntansi Going Concern, 13(2), 160-168.

Santoso, V. (2018). Analisis Perbandingan Manajemen Laba Pada Perbankan Syariah dan Perbankan Konvensional di Indonesia. Parsimonia, 4(3), 363375 . 
Schipper, K. (1989). Commentary on Earnings Management. Accounting Horizons, 3(4), 91-102.

Scott, W. R. (1997). Financial Accounting Theory. USA: Prentice Hall.

Scott, W. R. (2000). Financial Accounting Theory (Second edition ed.). Canada: Prentice Hall.

Scott, W. R. (2003). Financial Accounting Theory (Third Edition ed.). USA: Prentice Hall.

Stolowy, H. \& Breton, G. (2004). Accounts Manipulation: A Literature Review and Proposed Conceptual Framework. Review of Accounting and Finance, 3(1), 5-92.

Stubben, S. R. 2010. Discretionary Revenues as a Measure of Earning Management. The Accounting Review, 85(2), 695-717.

Subadriyah., Sadiyah, M., \& Murniati. (2020). Praktik Manajamen Laba: Sebuah Kajian Studi Hermeneutika. Jurnal Ekonomi dan Bisnis, 23(2), 225-242. doi: https://doi.org/10.24914/jeb.v23i2.2129

Ulupui, I., Buchdadi, A., \& Yusuf, M. (2019). Akankah Akrual Diskresioner Memengaruhi Kompensasi Direksi? Jurnal Ilmiah Wahana Akuntansi, 14(2), 200-219.

Watts, R. \& Zimmerman, J. (1986). Positive Accounting Theory. New York: Pratice Hall.

Yimenu, K. A. \& Surur, S. A. (2019). Earning Management: From Agency and Signalling Theory Perspective in Ethiopia. Journal of Economics, Management and Trade, 24(6), 1-12. 